\title{
S11 Fig
}
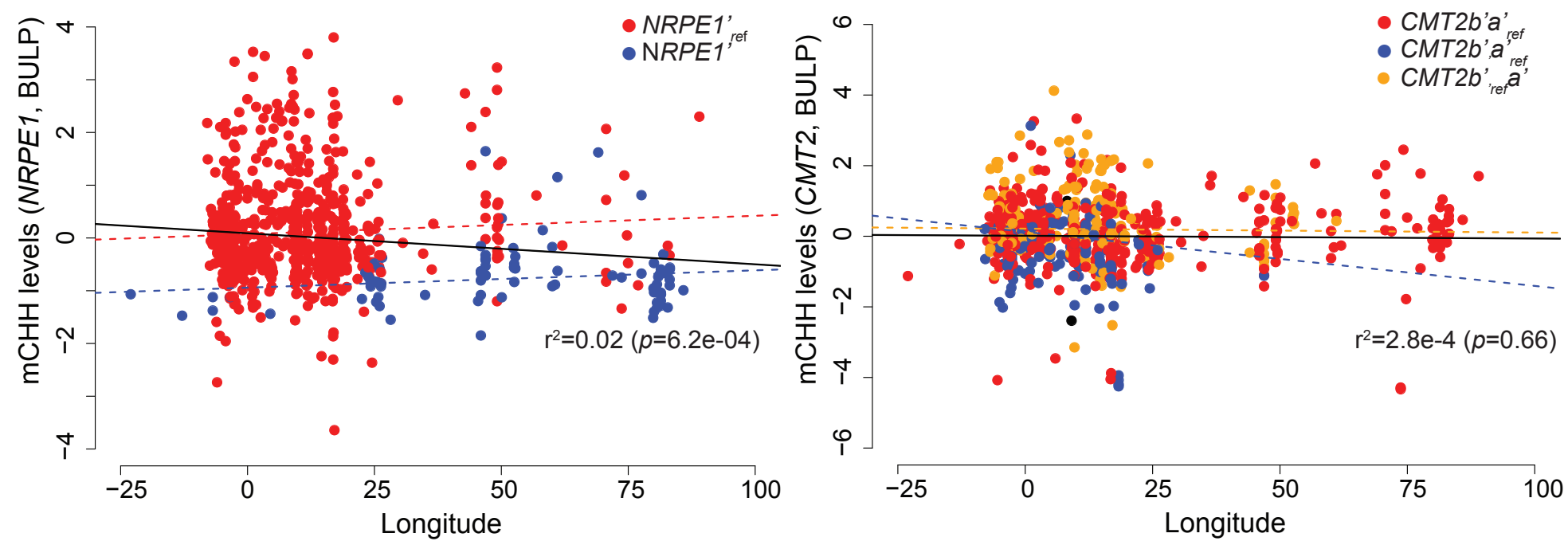